\title{
CIVIL DEFENCE IN INANGAHUA
}

\author{
T. E. Moore*
}

\section{(a) Formation and work of Civil Defence Committee in Inangahua County}

A Civil Defence Organisation has been operative in Inangahua for many years but because of the departure of many key personnel from the District, the Organisation was being re-constructed at the time the earthquake occurred. About six weeks prior to the earthquake Constable Le Fevre and I decided that the unit should be reactivated and it was arranged that he meet Council with a view to inciting more interest in the organisation. Following this meeting one Civil Defence Committee meeting was held, but time did not permit to formulate a new plan or procedures before the earthquake.

The main quake occurred at approximately 5.25 a.m。 Little was known of the desree of damage elsewhere or even the epicentre of the quake until quite late in the morning. Eventually it was established that Inangahua had been extensively damaged and that one person was missing and two injured, At this stage, ap roximately 11 a。no, a state of emergency was declared. Telephone communication with Regional Jeadquarters was established at 12 noon when Brig。 Burrows was informed of the situation. Igain at 1 pom. as a result of a further telephone call he was able to arrange the evacuation of the Inangihua aren. Durinir the afternon Civil Defence Ileadquarters were established at the New 'aenland Forest Service premises in Crampton Rondo New sectionil of icers were appointed due to many positions not being occupied for viriolus reasons, minly attributable to the earthiudic。 Therefore, a comparatively new and inexperienced team was responsible for the efficient running of the orcanisation throughout the exercise and, as Controller, I must pay tribute to the en "re staff for the assistance so willingly siven and the duties so readily performed. From the offset the Police, Air force, Army and the several Government Departments were of considerable help.

\section{(b) Operations in rescue}

Immediately the emergency had been declared the safety of the people in the Inangahua area became our first consideration. Reports had filtered through that there was a potential danger from the damming of the Buller River in the upper reaches. After consultation with Engineers and other officers it was decided that Inangahua Camp should be evacuated. Discussions were held with the Regional Commissioner, Brigadier J. T。 Burrows, who immediately co-operated by instituting a survey of the river and the engaging of Helicopters N.Z. Ltd. and the directing of the Air Force Iroquois to the area. Rescue operations commenced during late afternoon, in the first instance using the smaller Bell machines which were joined by the larger iir Force machines towards evening. A shuttlecock service was arranged from Inangahua to Rotokohu。 At Rotokohu buses, station wagons and cars conveyed the evacuated people to Reefton Forestry School where Civil Defence Headquarters had been established. Initially all road access between Reefton and Inangahua was cut. Access through Brown Creek Road was restored and some people were evacuated by motor transport by this means. 
Of necessity the helicopters were required to fly to and land in very difficult areas, flyine late into the night, landing under conditions that were hazardous because of the terrain, the continual fog and the encroaching darkness. Flying continued until $7.30 \mathrm{pom}$ on the 24 th liay when conditions became too dangerous for further flying. The following moming at first light, the remaining 30 persons were flow out of the area. The entire operation was carried out without incident, but it was necessary in a few cases to have the men folk leave their properties by force. The Police accompanied the fir Crew and brought these people to Reefton for registration. Once registration formalities were attended to they were then permitted back to the area to tend their stock, etc。 The assistance of $10 c a l$ bus proprietors, Departmental personnel and private car owners greatly facilitated the transport of the evacuated persons from Rotokohu to Reefton. Without the air lift the evacuation of the area could have been a very difficult and long exercise. An Iroquois was used later to transport an earthquake victim from the Inangahua Hospital to Christchurch Hospital. This patient was not able to be transported by road because of her condition and required urgent specialist treatment。

(c) The Velfare section was one in which some activity had been taking place. A lady Councillor, Mrs Ao Hardie, had attended a recent Velfare Course at Lincoln College and on her returm had interested herself in this work. First Aid lectures to about a dozen interested women had been arranged, and one only had been held prior to the earthquake. Names of residents willing to take billets had been obtained and before the emergency billets for 50 people had been scheduled. On the first night however we were able to house 250 people in Reefton. This was made possible by the wonderful response given by the people of Reefton to requests through the local Broadcasting station.

The Forestry building proved an ideal establishment for the providing of the several phases of Velfare which followed immediately upon the rescue work. Large spacious rooms were available for reception, welfare, catering, clothing, registration and the provision of personal services. The Velfare section carried out all these functions as well as catering for many people associated with Civil Defence, Government Departments, Army, Air Force and working parties, Voluntary workers from Ladies Organisations assisted by Girl Guides and Secondary School girls provided a very necessary service. Material assistance was given by the Salvation Army under Captain James Brown of Greymouth, who organised the reception and delivery of furniture, clothing, foodstuffs, etco as well as contributing. $\$ 2000$ in cash for immediate release to the evacuated people. Red Cross too contributed $\$ 1600$ for similar purposes, in addition to forvarding many parcels of clothing, foodstuffs and furniture. other organisations besides the two mentioned played a great part in providing this welfare that was so vital to the people at the time.

\section{(d) Works}

As soon as possible after the rescue and the providing of the necessary Welfare, consideration was given to restoration of roads, bridges, electric porer and telephone lines, supply systems and other essential services. In addition farmers were oblised to return to their farms to attend to their stock and other farm duties. Ministry of Works, New Zealand Plectricity Department, Post and Telegraph and Railway gangs were soon established. The Iroquois again played a very important part in transportation. Many work parties, professional people, farmers and press representatives were able to use this service. i system of priorities was set up, and the utmost advantage was made of these machines. Stock food was dropped at some isolated farms. 
The speed with which roading, rail, power and telephone works were restored was an object lesson to all. The Engineers in charge appeared to have the various jobs formulated before any time had expired and the works gangs carried out a considerable amount of work under most difficult conditions. Not only were they working under difficulties but on return to their respective hotels and accommodation houses these people lived under difficult conditions, for the hotels and accommodation houses were overflowing with guests, many of whom were provided with make-shift accommodation. These premises were not always capable of providing such amenities as drying rooms for wet clothing and many beds were made available in hotel lounges and balconies where rest was sometimes interrupted. The Hotels, too, were void of heating due to the loss of chimneys by earthquake.

Assessment of damage to property was comnenced on the day following the earthqualke. Professional and administrative officers of the Earthquake and Tar Damage Commission were in the field at a very early stage。 Insurance adjusters commenced work the same day and very soon local men and women were trained to man the office to process the many hundreds of applications that were channelled through to them. This good work continued throughout the Civil Defence exercise, and a Committee was set up to prepare lists of priorities and arrange contracts。 Preference was given to aged persons, widows and couples with large families who required urgent chimney and roof repair work carried out.

Some demolition and closure orders were found necessary, One hotel and one brick house were declared unsafe for habitation by Civil Defence Ingineers while the Post Office was demolished following a report of a structural engineer. All schools, public buildings, swimming baths, slaughterhouses, hotels were the subject of separate engineering reports. Likewise reports on such items as the slip on the hill at Inangahua Junction and other aspects of roading and bridging that may have been considered dangerous were readily available from the Geologists and Engineers on the spot. I am very conscious of the material assistance these professional people have given to Civil Defence in this instance and I cannot advocate too strongly the need to have these experts flown to the disanter area and their services or reports made available to Civil Defence durins the period of emergency。

\section{Problems of Civil Defence}

The Pmergency was declared at 11 a.m。 on Friday 24 th May, and uplifted at $6 \mathrm{pom}$ o on Thursday, 30 th May. During that time many problems were encountered, the major problem being communications. Communications through normal channels were out of operation until late in the afternoon of the day of the earthquake. Telephone communication, through the N.2. Railways telephone system, with Christchurch Regional Headquarters was established at 12 noon。A Radio link between Greymouth and Reefton was made through the Transport Department's radio equipment. The Forestry Department was able to receive messages from Golden Downs, Nelson Area and I believe the Post Office, Reefton received a message approximately 9 a.mo to the effect that a person was missing and others had been injured at Inangahua. Trom all reports received all radios appeared to be playing up and the communications made were poor. There appeared to be a good deal of confusion on receipt of these early messages and they did not reach Civil Defence Headquarters. Co-ordination was extremely poor at this early stage。

Troubles continued with communications. The manual exchange at the Reefton Post Office was working under difficult conditions. The loss of toll circuits together with intermittent interruptions experienced on 
those circuits which were first restored meant that Civil Defence calls could not always be given the priority requested. The Reefton Branch of the T.A.B. was closed to obviate too much traffic on the Po. $2 . T$. Iine。

Another important aspect that created a problem of great magnitude was the fact that a good number of the officers appointed to the key positions were not available at the time of the emergency. The Signals Officer (also postmaster), the Transport Officer (also Stationmaster), were engaged in their respective departments. Had their services been available, particularly the Signals officer, it is presumed that the initial disorganisation of conmunications would not have occurred. Others not available were the Controller (County Chairman) whose home was at Inangahua, the staff Officer, Operations, Intelligence Officer, who were away on leave. Selecting and co-opting suitable staff to do these duties was difficult but those selected carried out their duties very efficient$1 y$ 。

The Supply officer experienced difficulty in procuring equipment and goods during the weekends, especially when drawn on the larger firms, for weekend access to principals or senior staff was not easy to arrange. Many people were absent or not near telephones。

Determination of what expenditure should be a Civil Defence responsibility after the uplifting of the emergency created considerable difficulty. Ministry of Works and a Co-ordinating Committee did assume full responsibility, but after a short period the Ministry of iorks intimated that matters of a welfare nature were not the Department's responsibility. This work has again fallen back on the Civil Defence Organisation who are administering it to date.

\section{Inangahua Disaster Relief Fund}

This has been contributed to quite generously and today the receipts total $\$ 18,000$ while the financial need to satisfy all reasonable and legitimate applications for assistance will probably be $\$ 100,000$ so the fund is far short of its required mark。

\section{Appreciation}

The people of Inangahua, whether resident within the disaster area or elsewhere in the County owe a great deal to other people throughout the length and breadth of New zealand. The response by the Salvation Army, Red Cross, Women's Divisions of Federated Farmers, Church Organisations and the very many other bodies and the individual cash donations and gifts by people not associated with other bodies has been fantastic. These gifts have been appreciated by all concerned.

I should like to express my apprecietion to Brigadier J. To Burrows, Regional Commissioner, Civil Jefence, Christchurch, and his staff for the manner in whicll my staff and $I$ were assisted during the emergency。 Every request was actioned immediately. The Brigadier, with his considerable experience and the wise counsel so villingly given guided us through quite a strenuous period。

\section{Conclusion}

Many of the inhabitants of the county were greatly shoclied by the earthquake. These shocked and distressed people were afforded immediate attention by the two iledical Practitioners at Reefton whose role at Civil Defence became a very personal one. A sick bay was established at Civil 
Defence Headquarters where Drs. Hertnon and Tiveniow attended daily。 Similar facilities were afforded the Vorks force at Inangahua Camp。 The services of these two grentlemen were greatly appreciated。

My entire staff join with me in expressing our deepest sympathy to the relatives of those persons who lost their lives as a result of the earthquake or in carrying out duties associated with earthquake damage. 